\title{
H2AB3 wt Allele
}

National Cancer Institute

\section{Source}

National Cancer Institute. H2AB3 wt Allele. NCI Thesaurus. Code C154655.

Human H2AB3 wild-type allele is located in the vicinity of Xq28 and is approximately $1 \mathrm{~kb}$ in length. This allele, which encodes histone $\mathrm{H} 2 \mathrm{~A}$-Bbd type 2/3 protein, is involved in the modulation of DNA compaction, which regulates gene transcription and mRNA processing. 